\title{
Selective and Environment Friendly Methodologies Based on the Use of Electrochemistry for Fine Chemical Preparation: an Efficient Synthesis of N,N'-Disubstituted Ureas
}

\author{
Isabella Chiarotto, Marta Feroci \\ Università degli Studi "La Sapienza", Dipartimento di Ingegneria Chimica, dei Materiali, \\ delle Materie Prime e Metallurgia, \\ via Castro Laurenziano, 7 I-00161 Rome, Italy \\ Corresponding author: Marta Feroci (e-mail: marta.feroci@uniroma1.it)
}

Supporting information: spectral data of ureas and oxamides. 


$$
E
$$




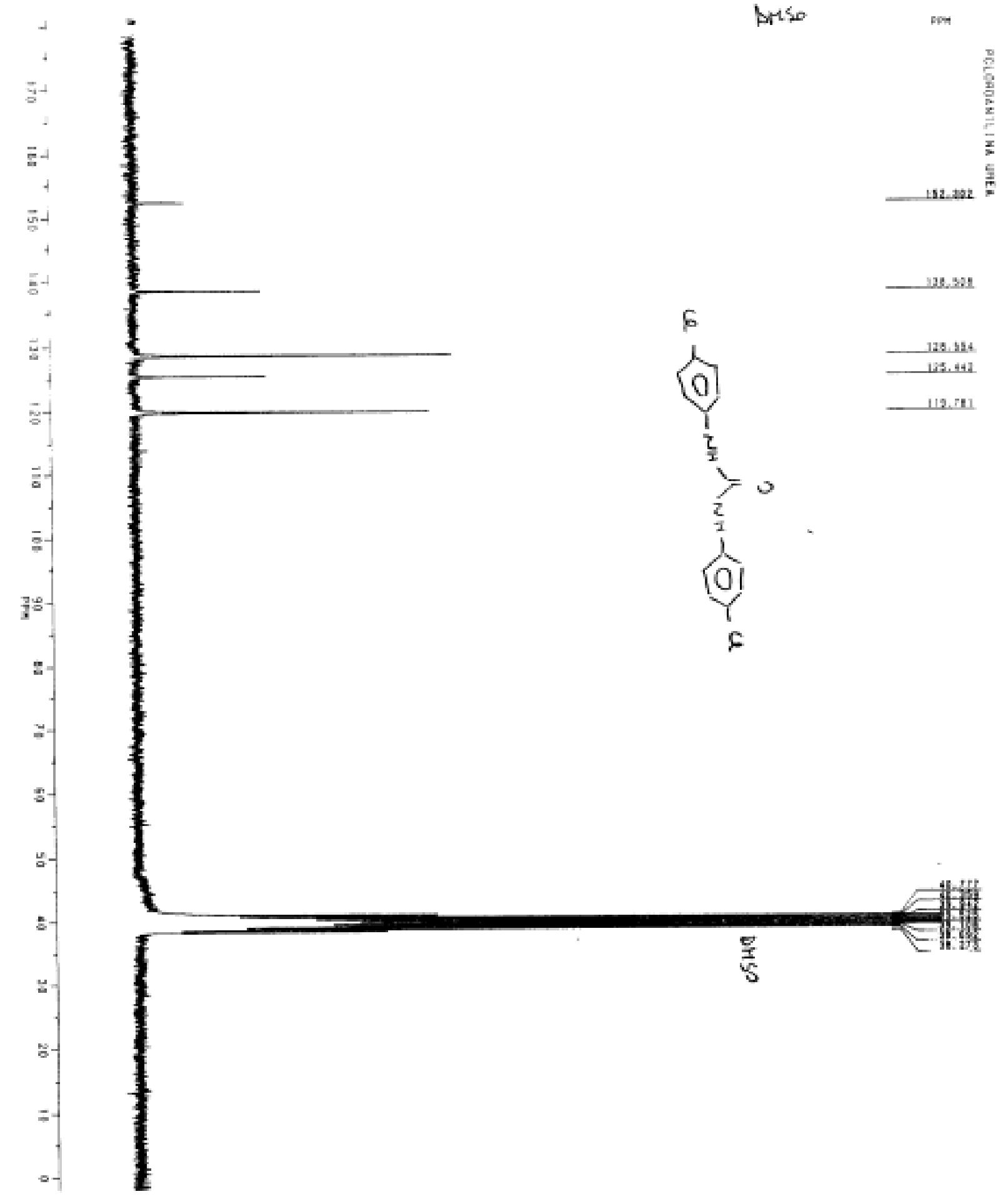




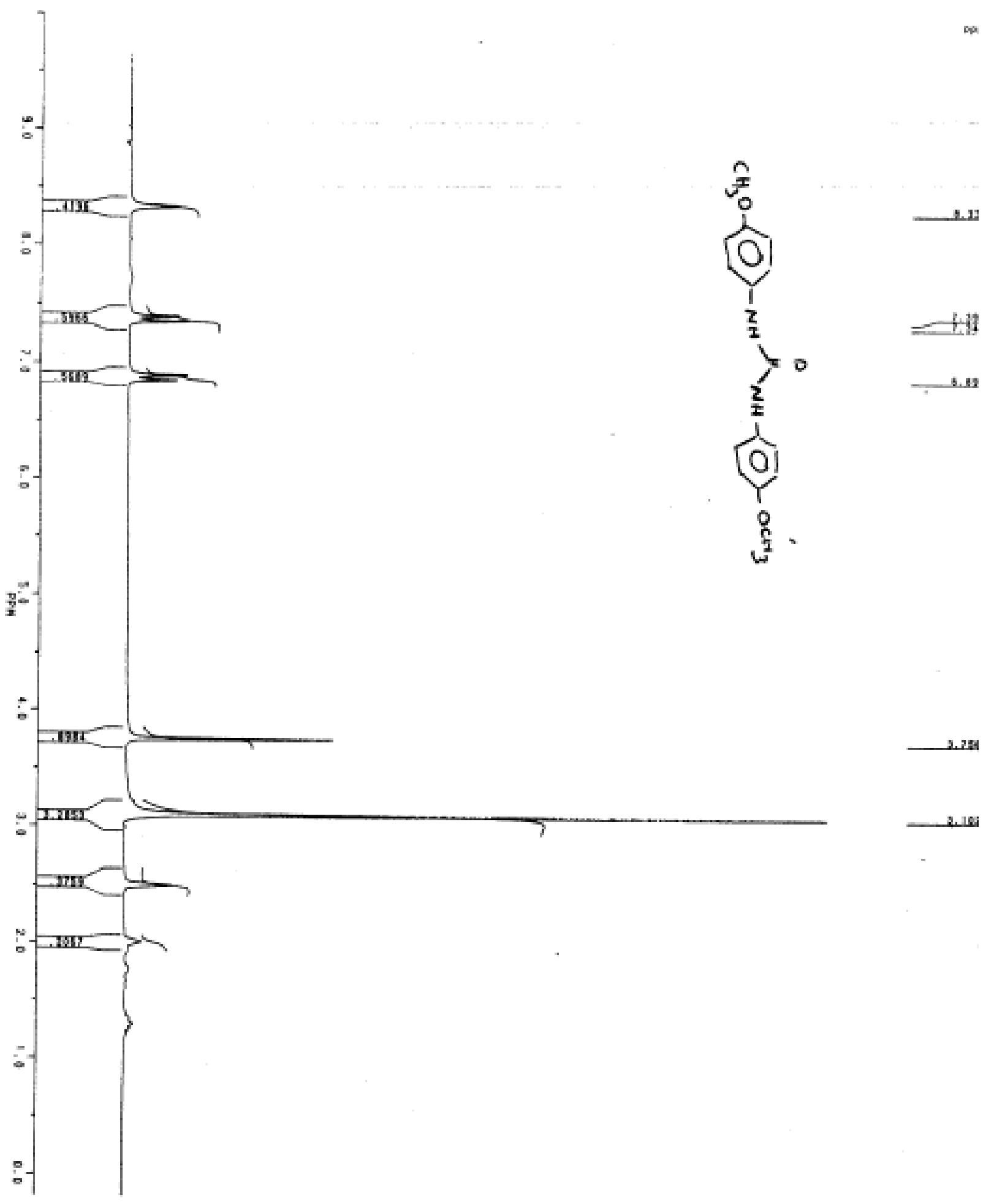




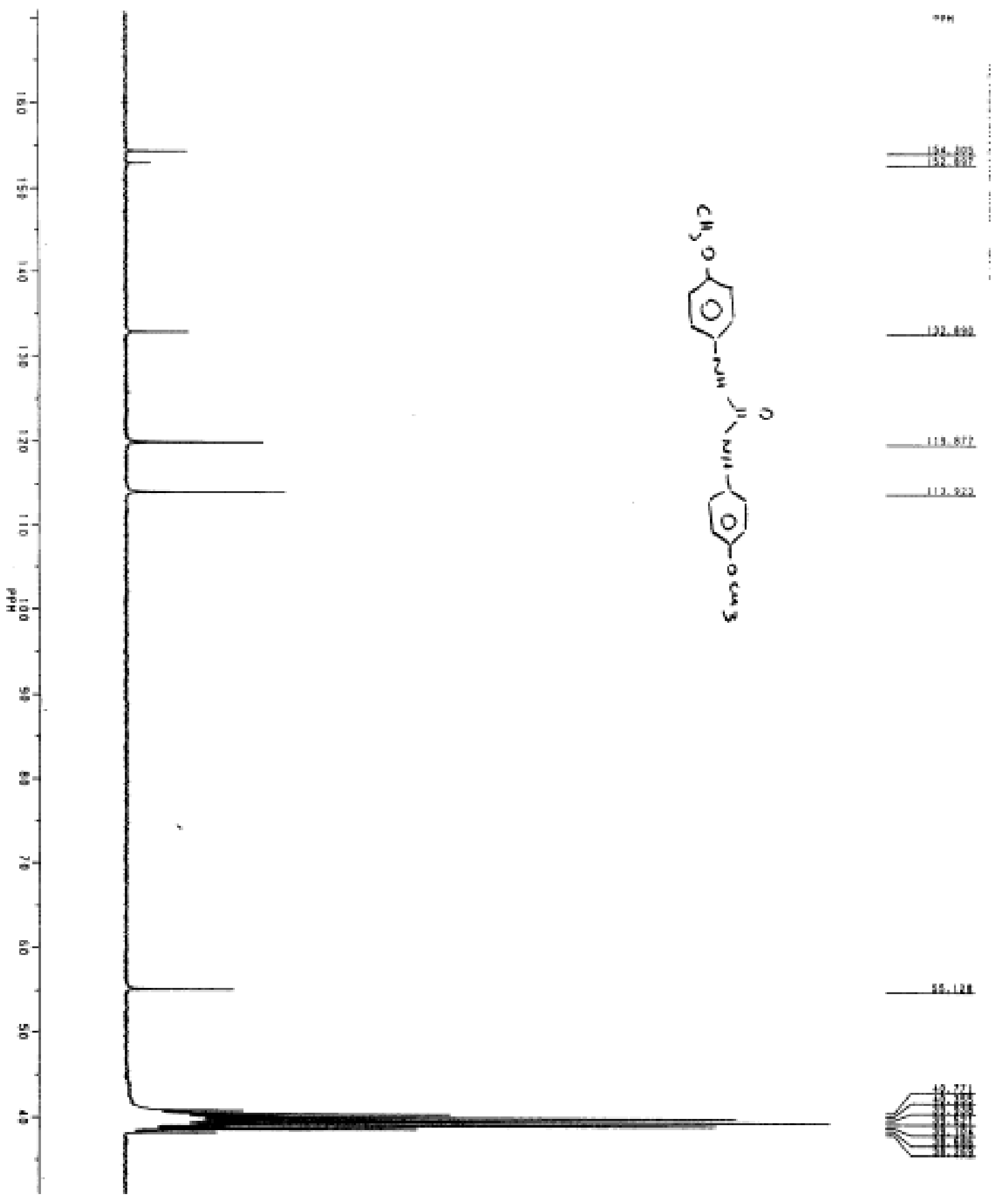




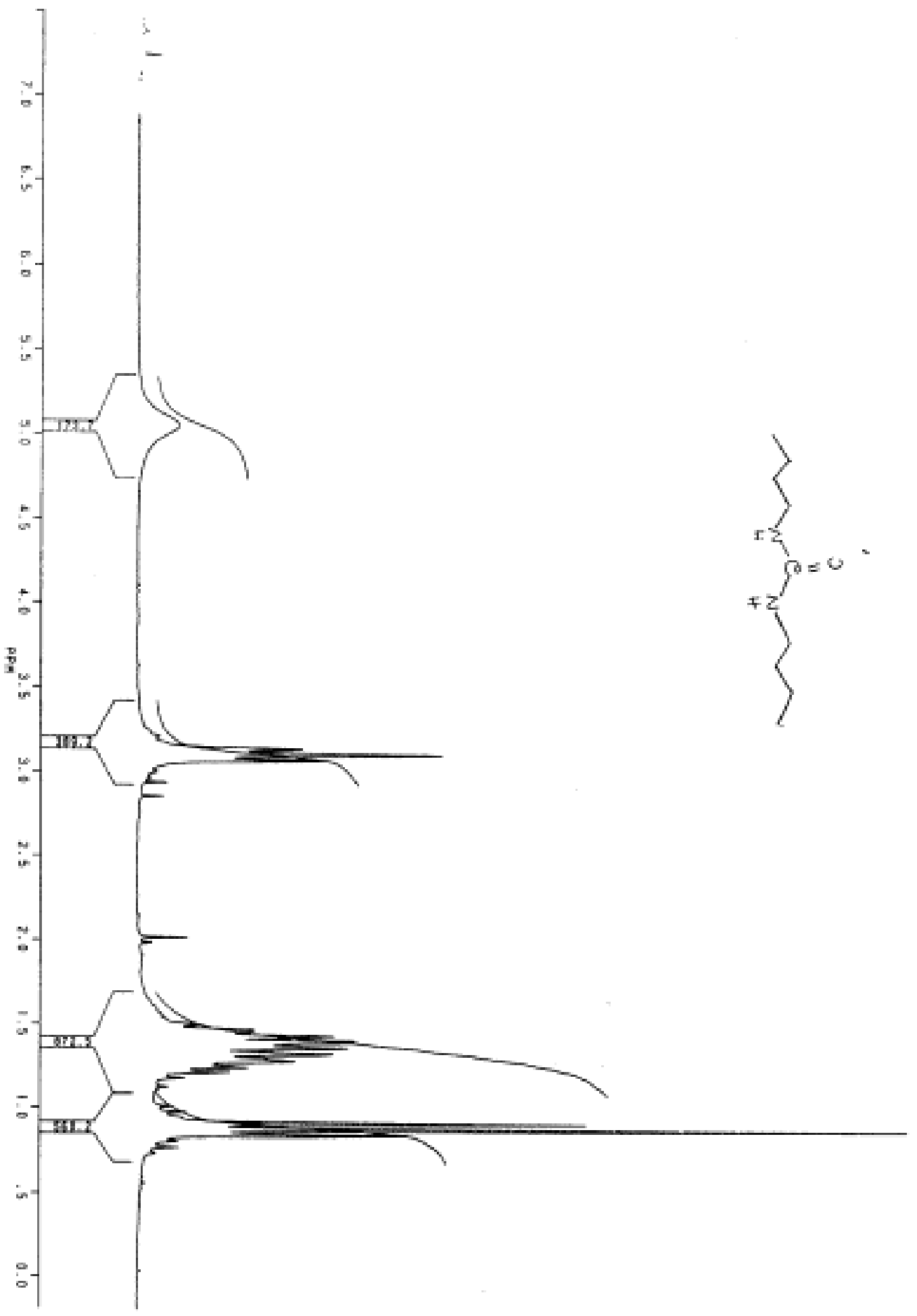

工科

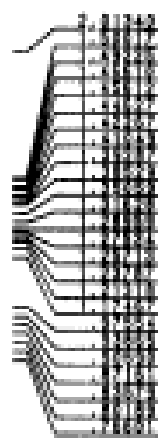



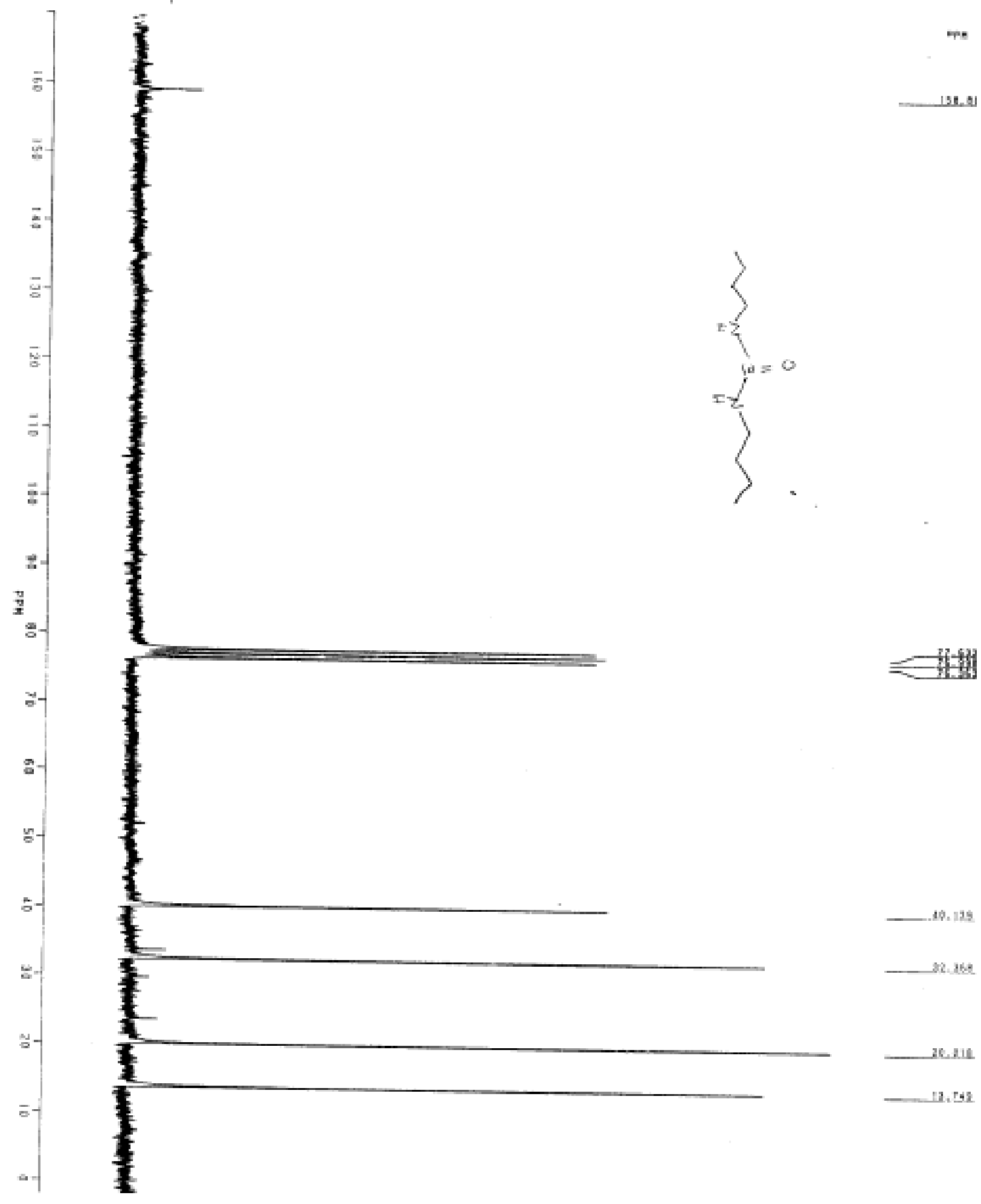

2e.ue 


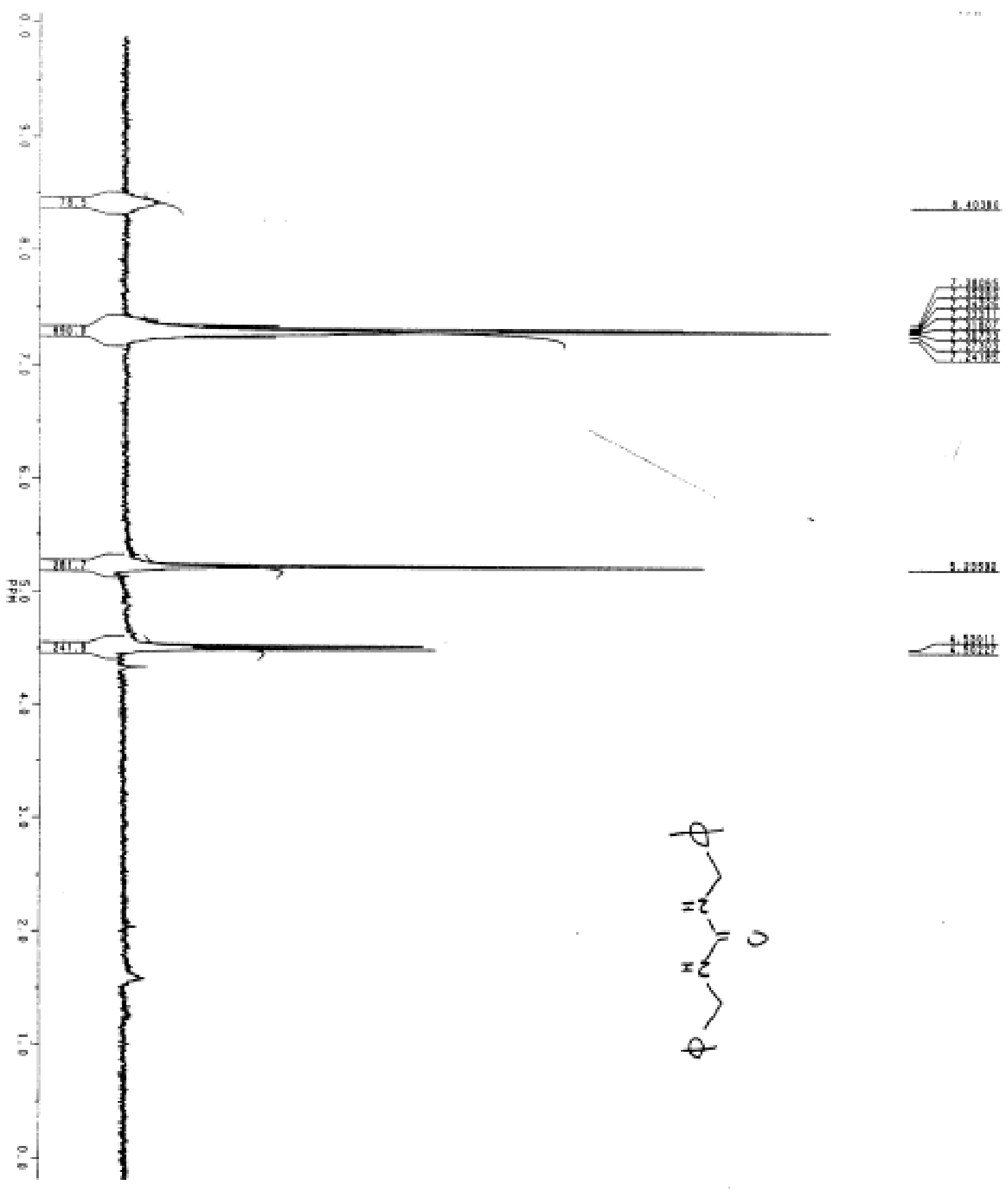




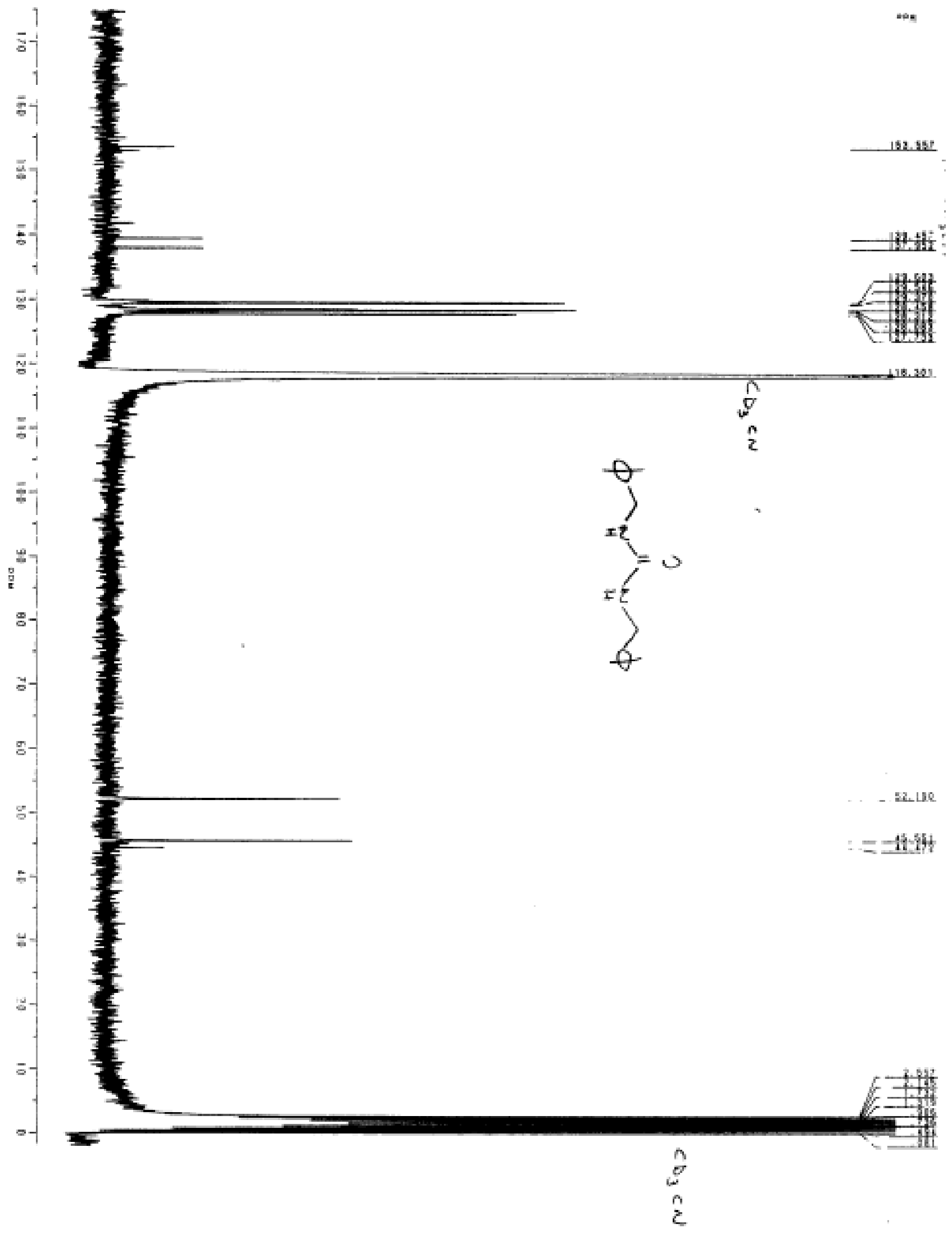




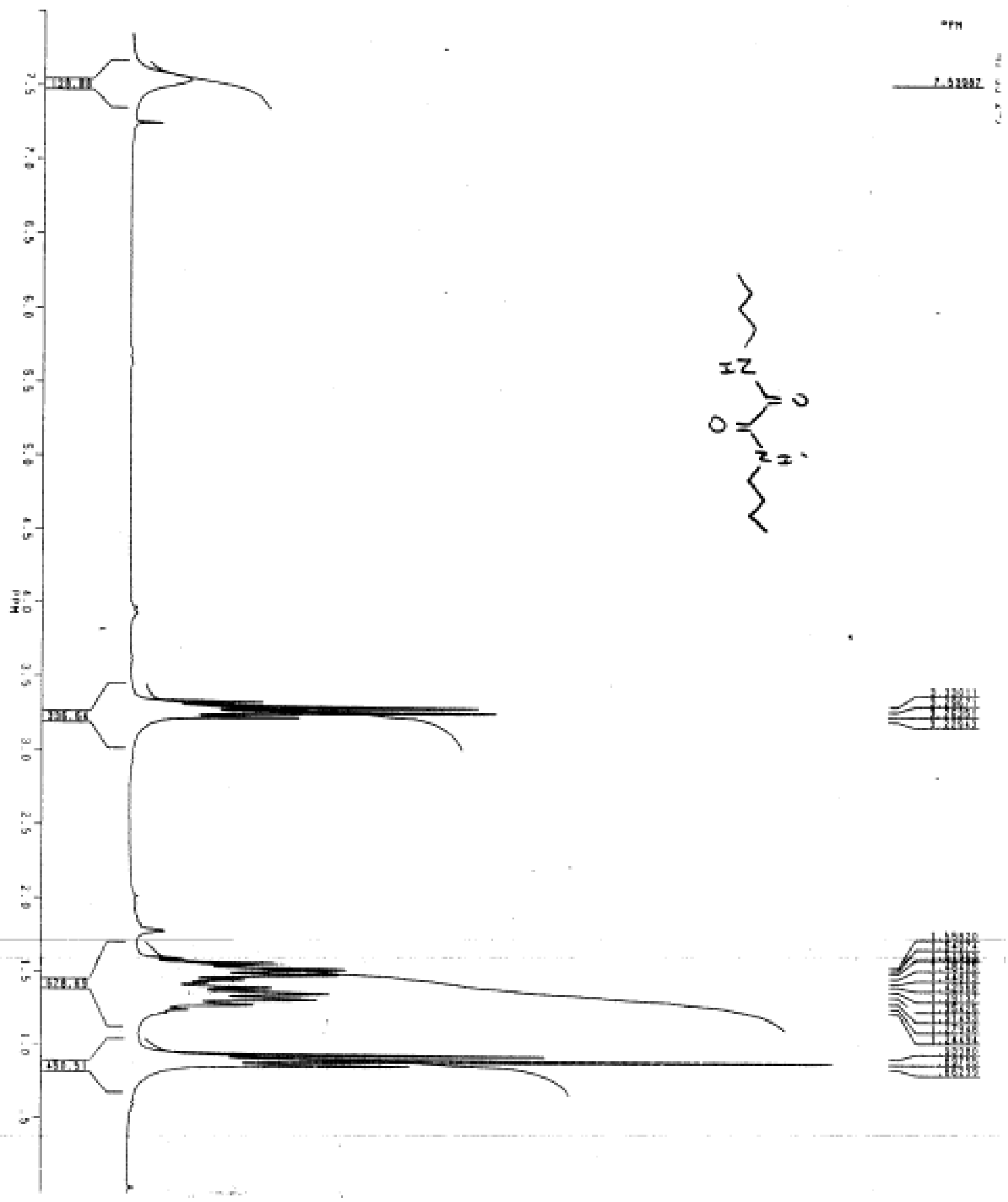




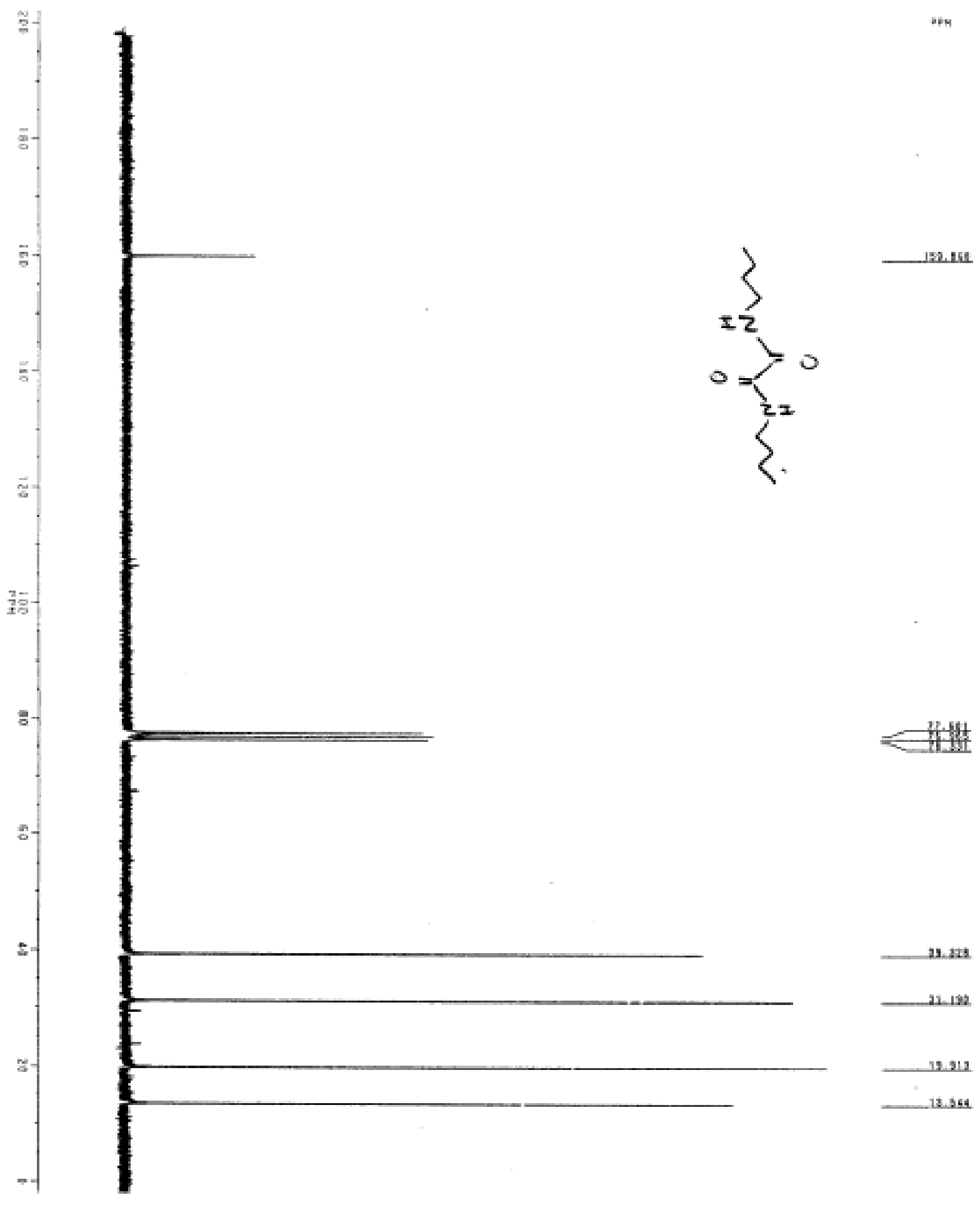



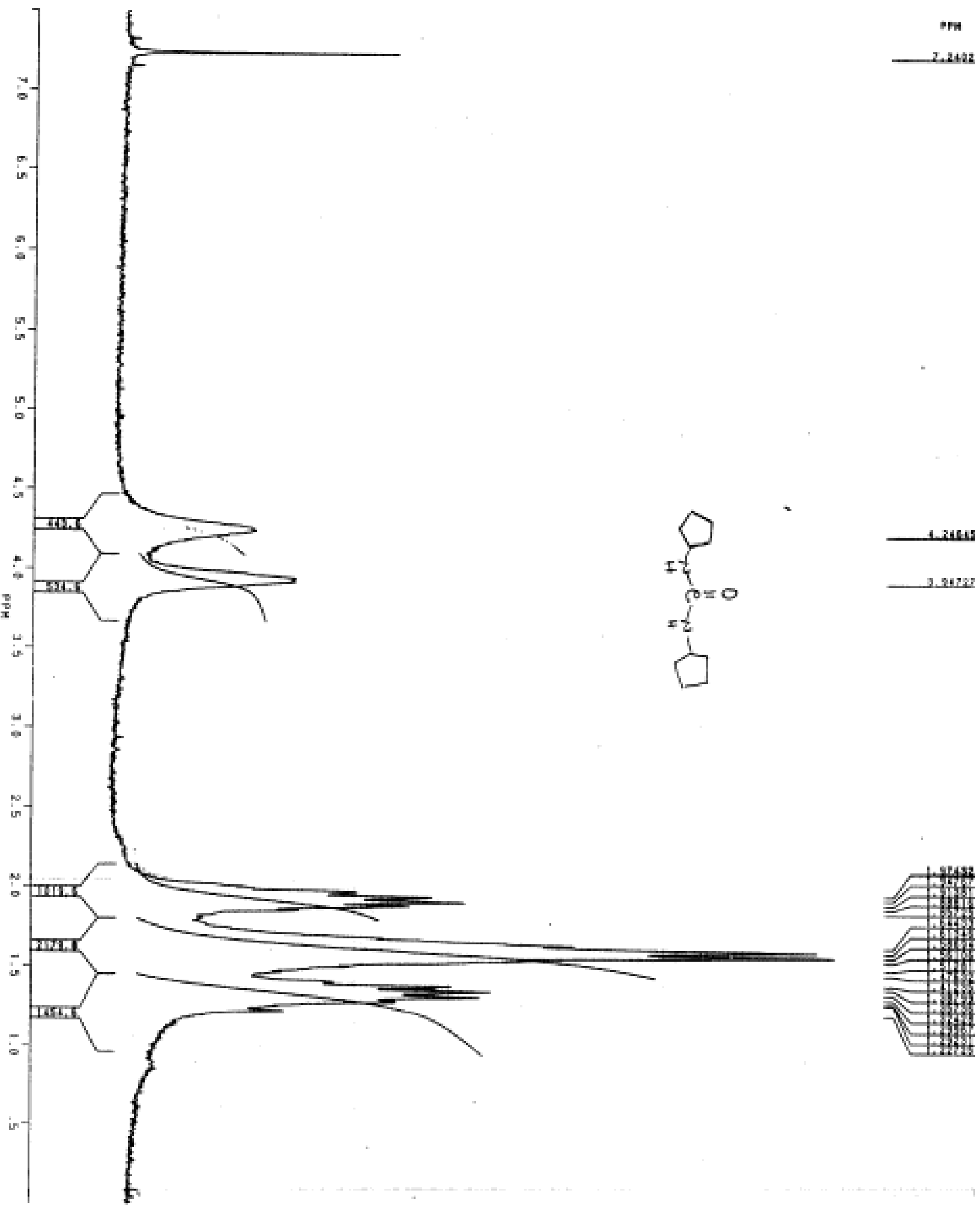


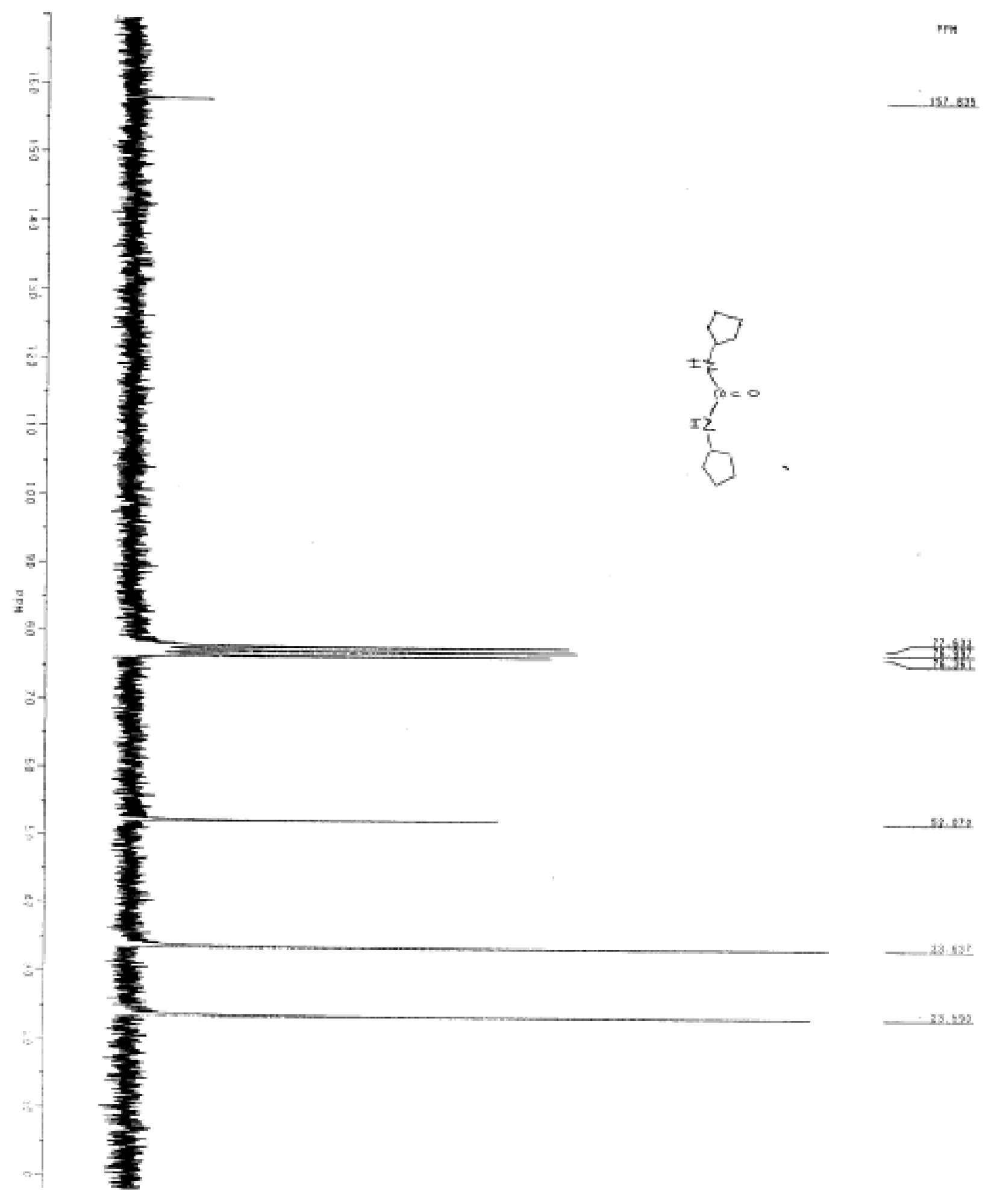




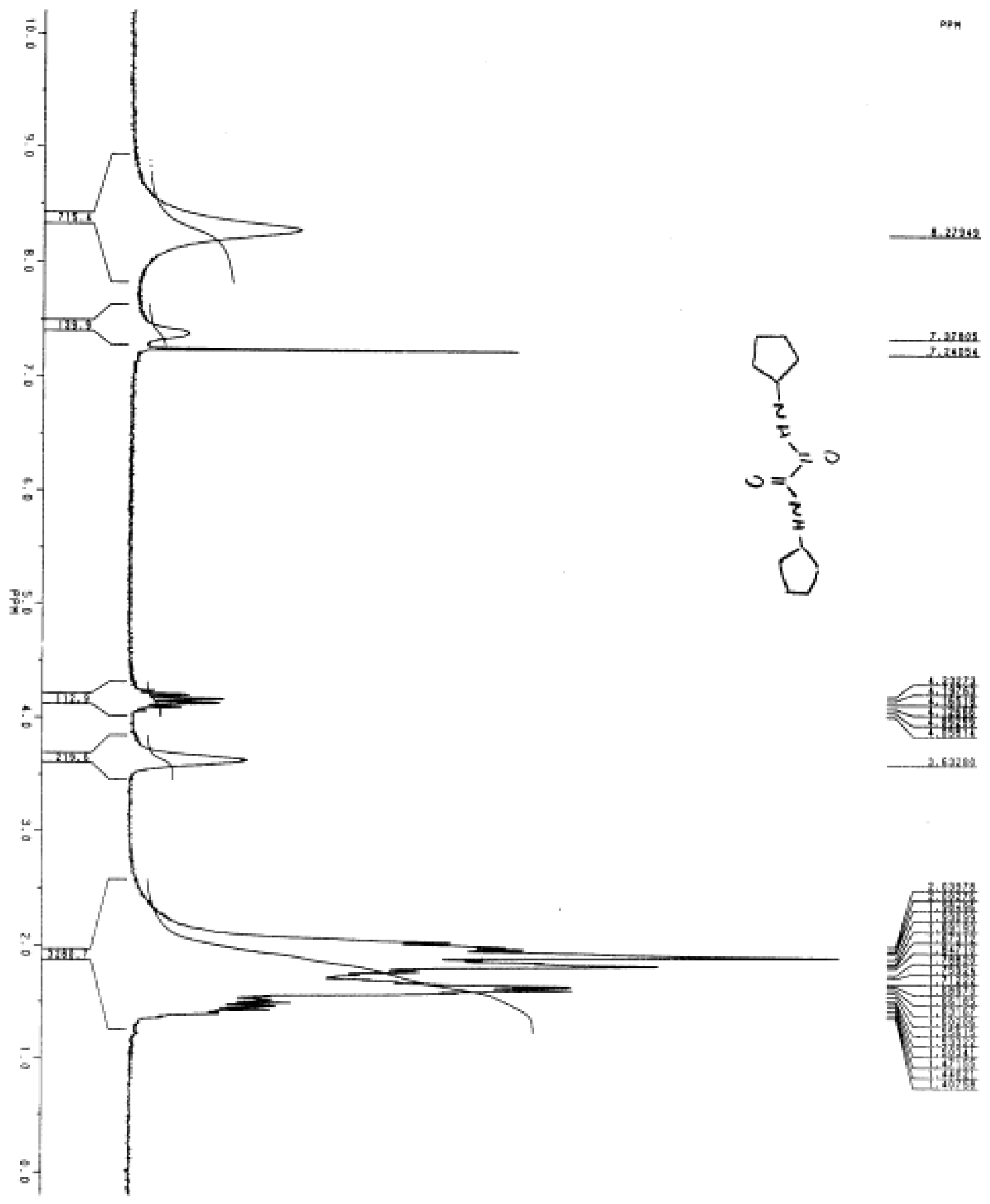




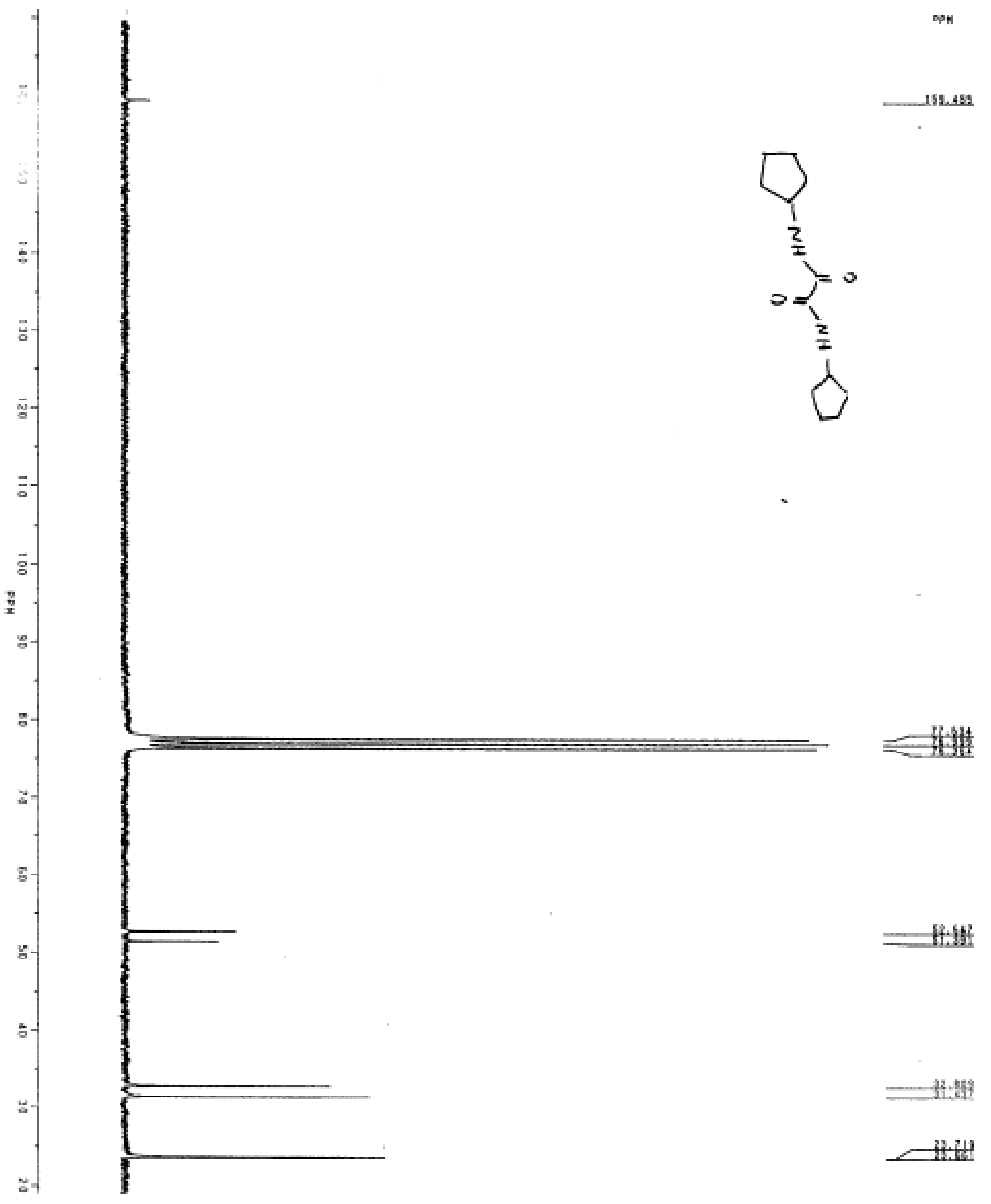



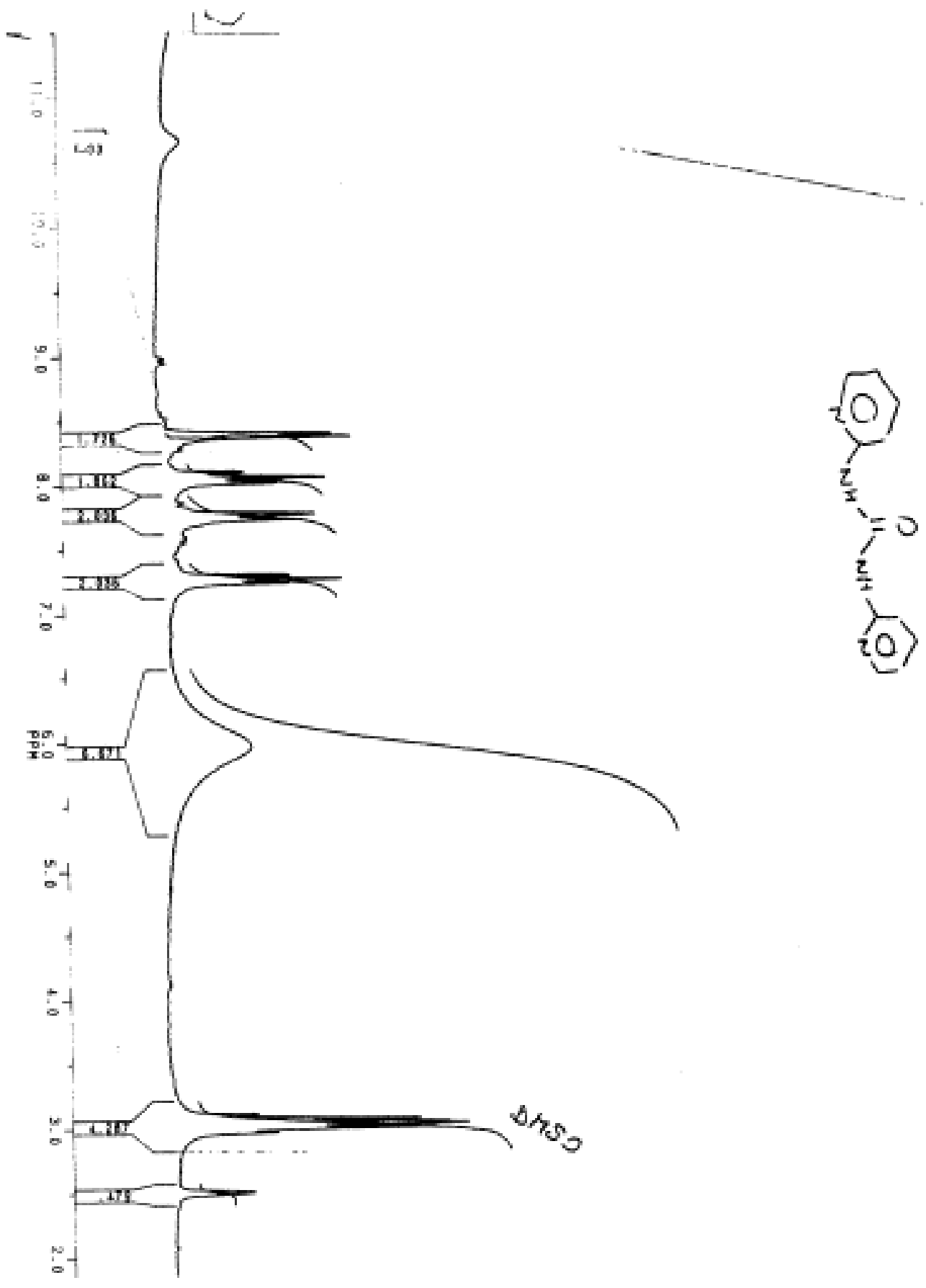

Lititill

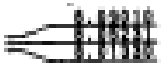

rit34

- 端等

이

E. 14852

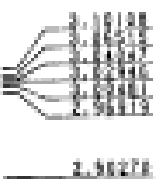




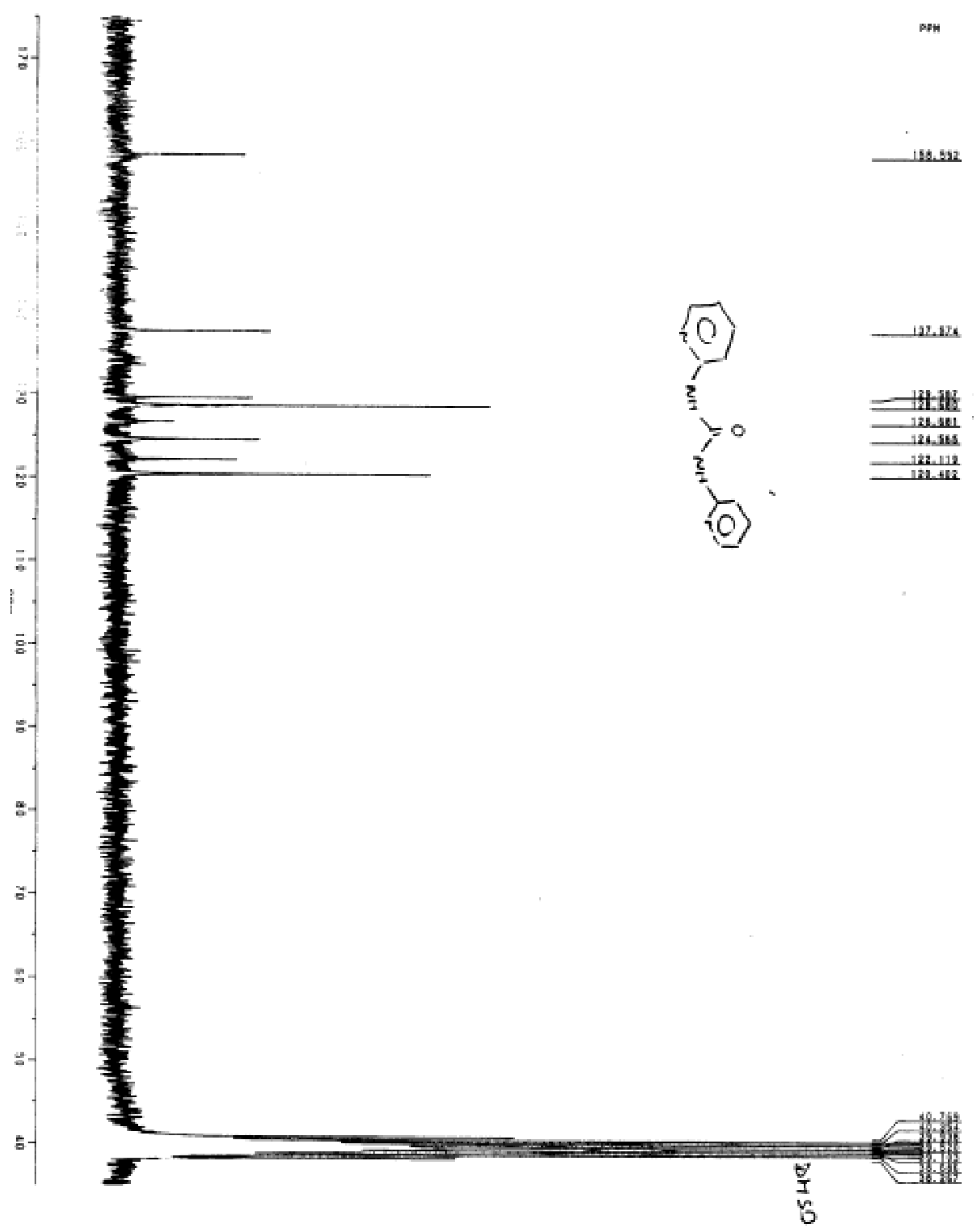



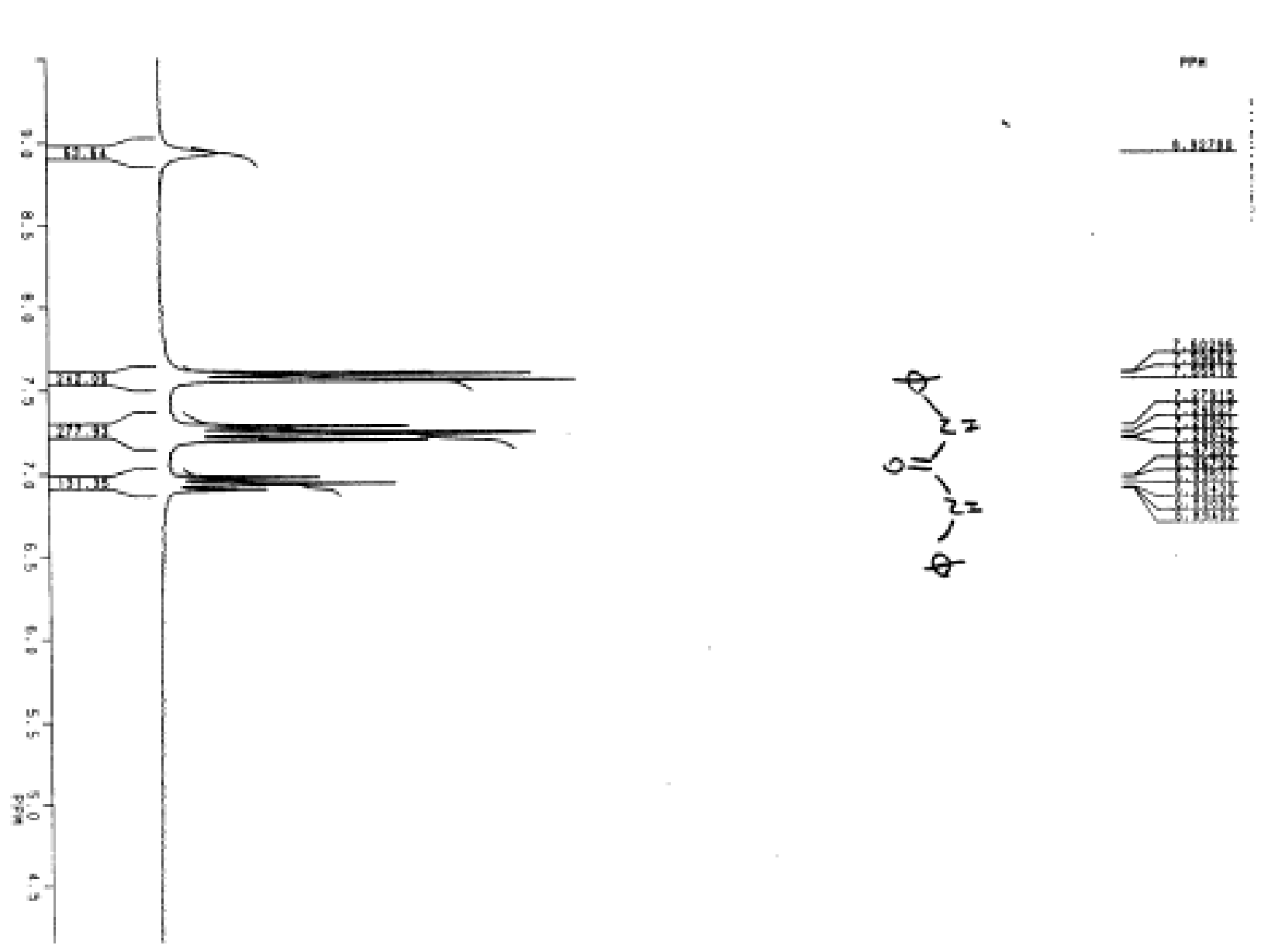


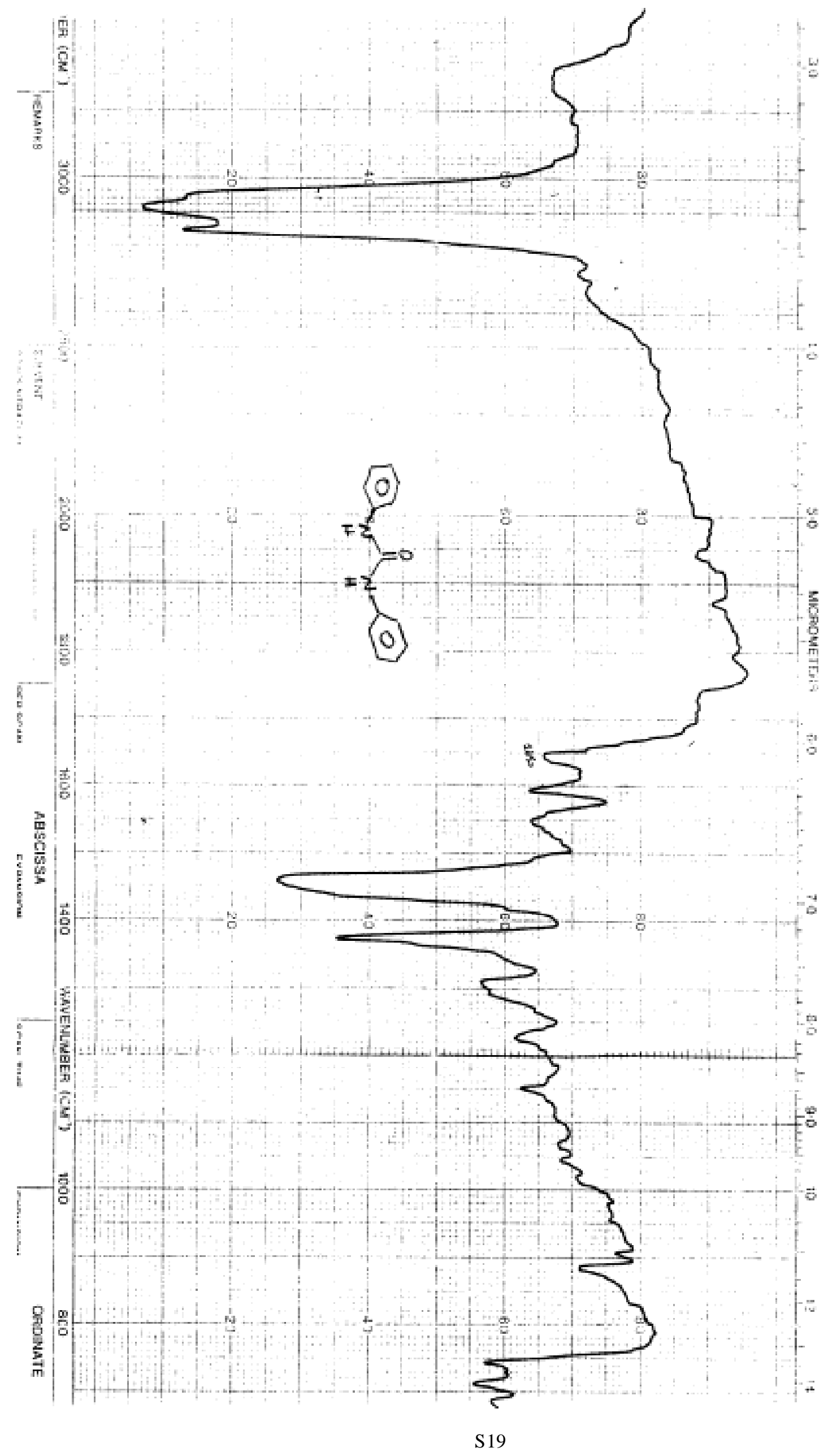




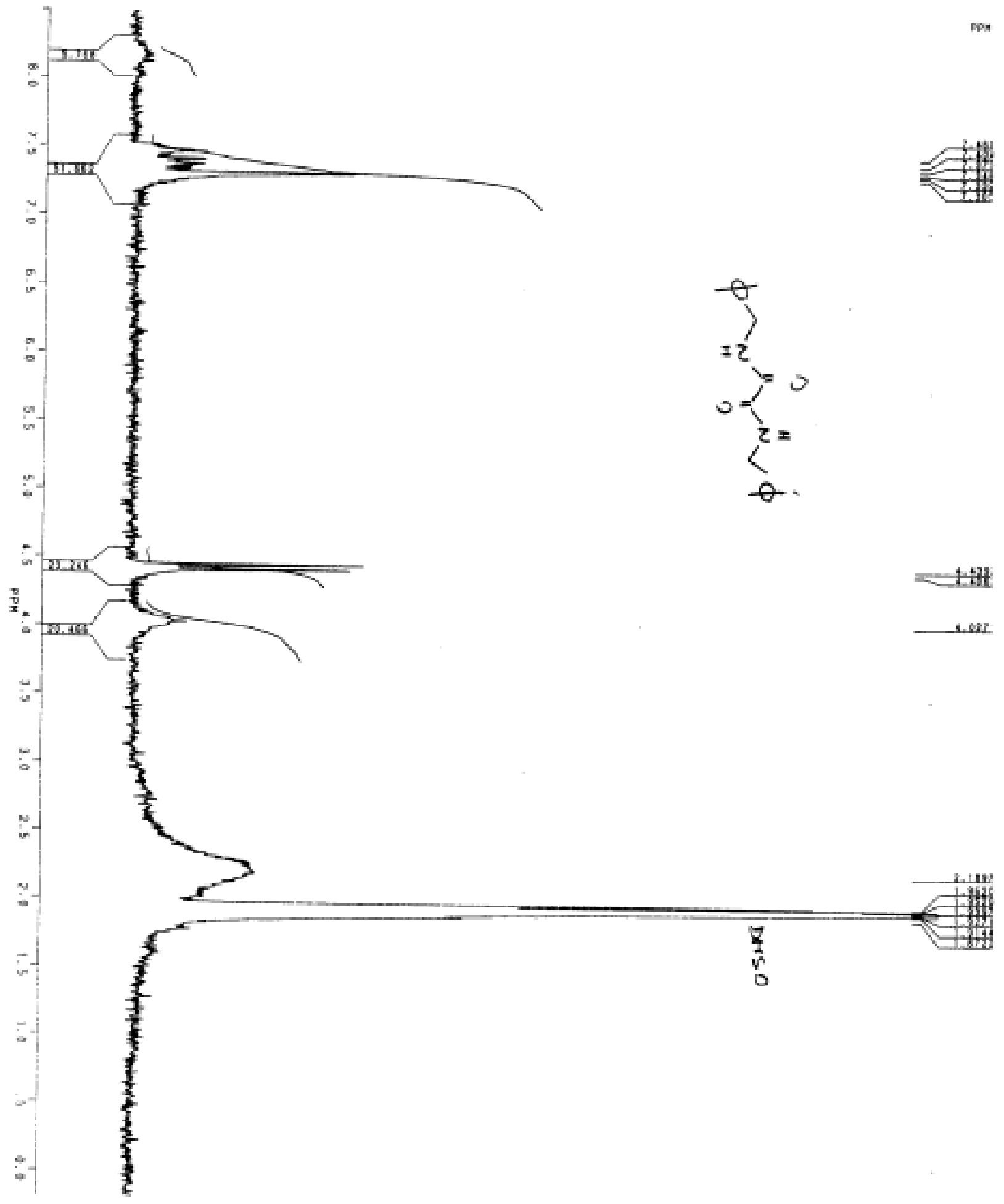



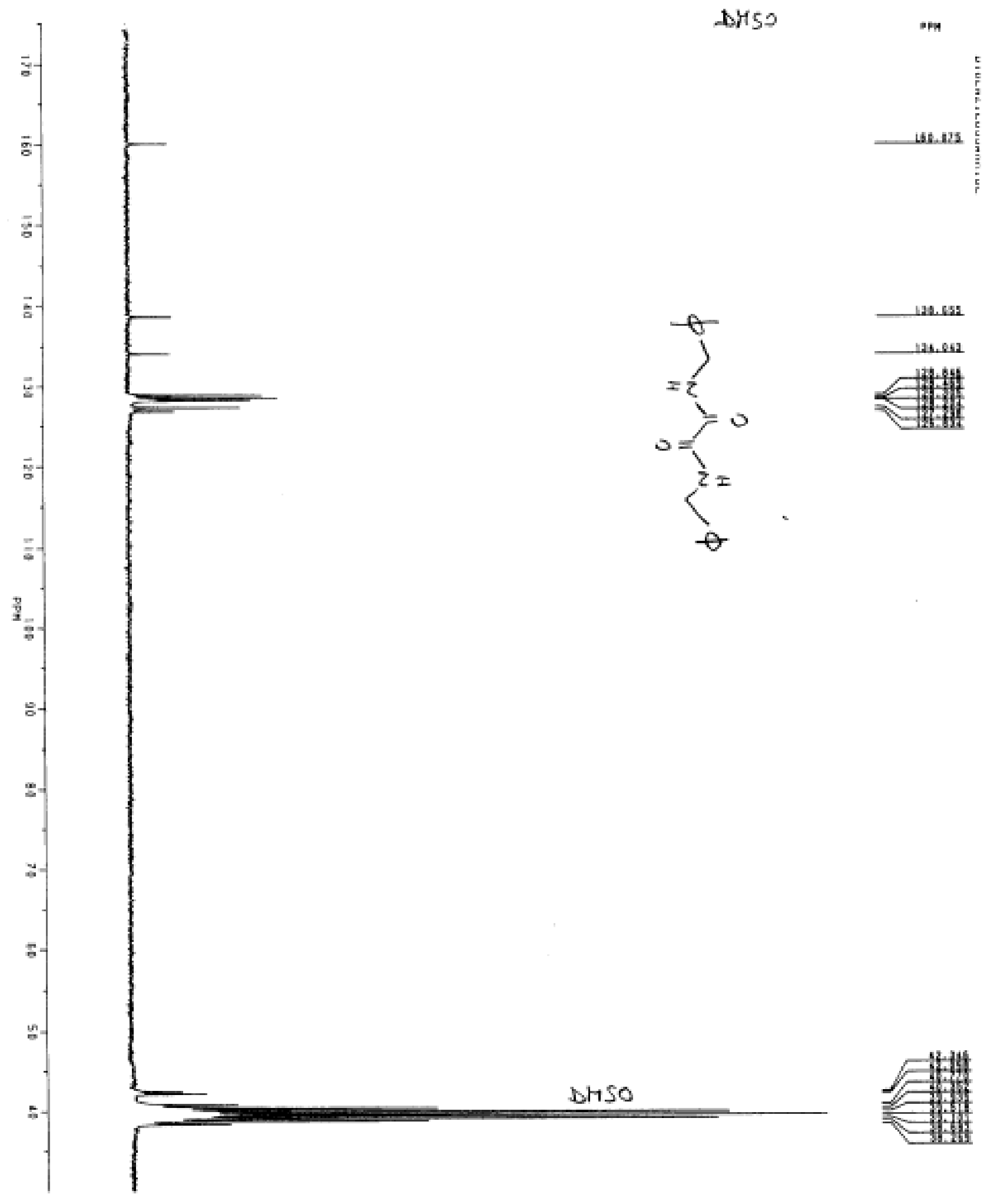

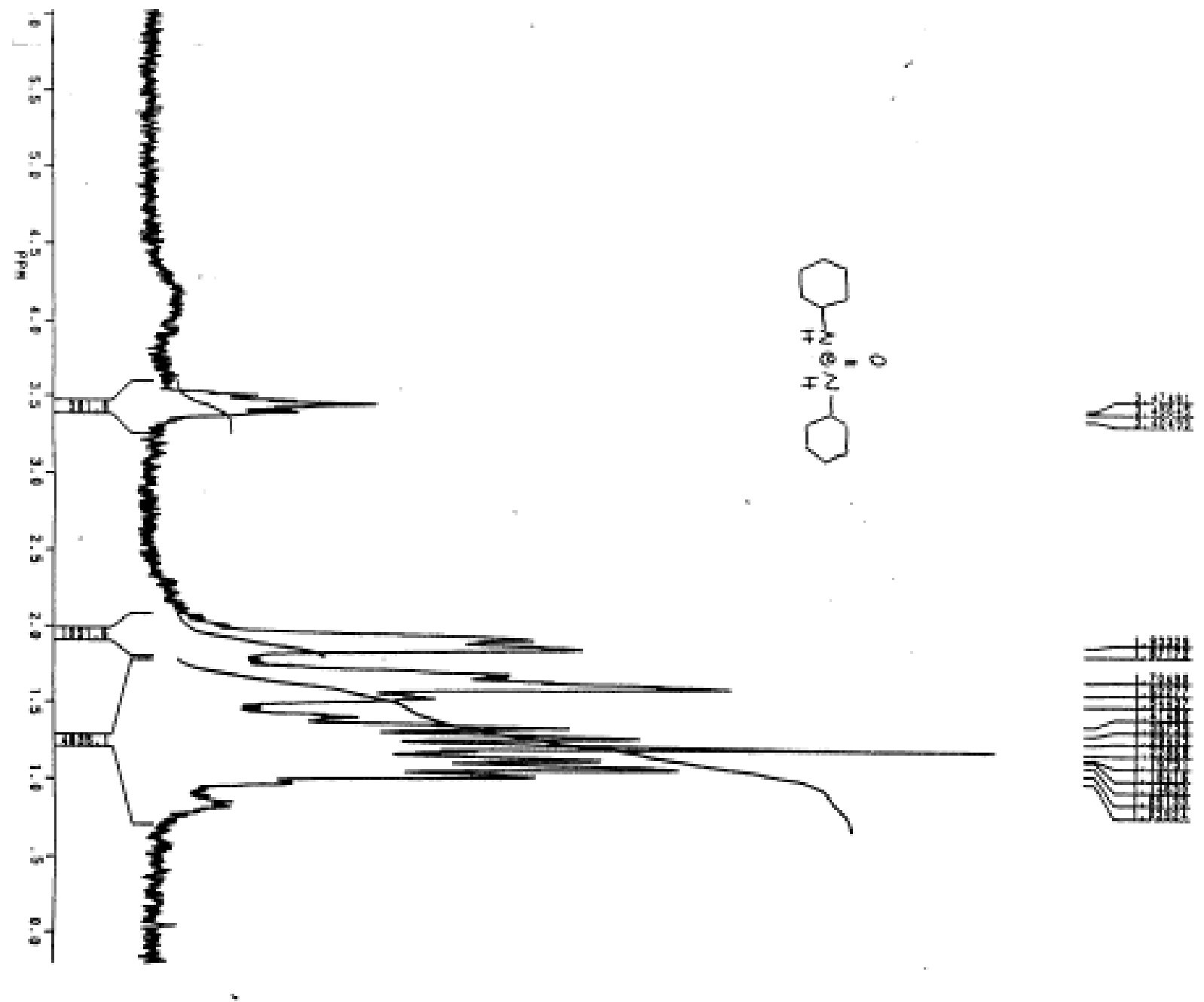


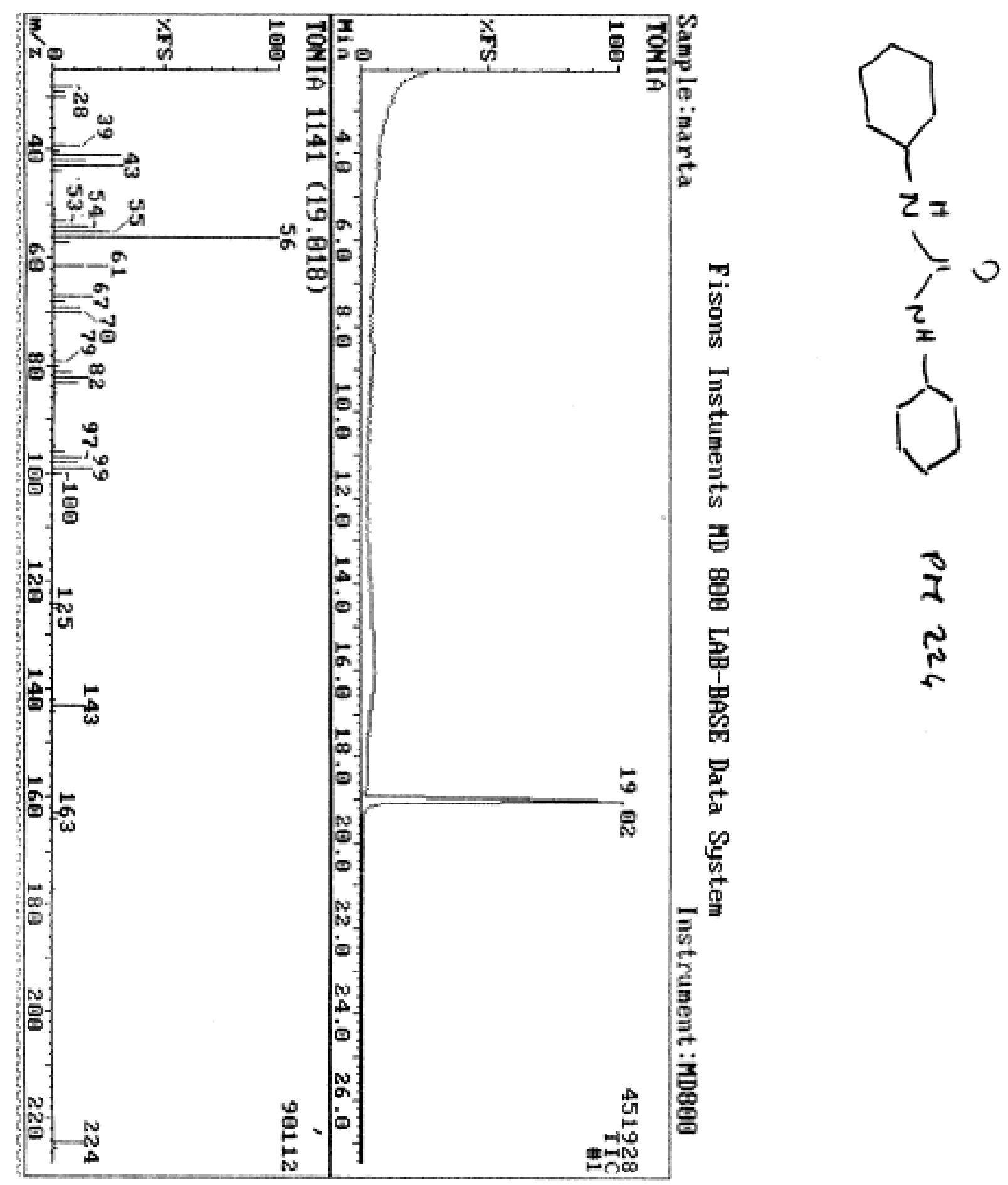

